\title{
Novel Remedial Approaches Against Virulent Corona Viruses
}

Surya Prakash Tadepalli

Physician, Surgeon, Clinical Microbiologist, Psychologist, Nutritionalist and Indian Classical Medical Movement Therapist, India.

\author{
"Correspondence author \\ Dr. Surya Prakash Tadepalli \\ Founder President \\ JSMKDO \\ Visakhapatnam \\ Andhra Pradesh \\ India
}

Submitted : 11 April 2020 ; Published : 8 June 2020

\begin{abstract}
Novel Corona virus disease (COVID-19) was first identified in China, which eventually became a major global health concern due to its pathogenicity and widespread distribution around the world. In the mid-sixties of the previous century, the first two human Corona viruses (HCoV) were identified: HCoV-229E and HCoV-OC43. These two human Corona viruses were studied extensively from approximately 1965 to the mid-1980s. HCoV-229E is a member of the group I Corona viruses, and HCoV-OC43 is a member of group II. 1 Besides the human Corona viruses, there are several group I and group II animal corona viruses that infect cattle, pigs, cats, dogs, mice, and other animals. There is one additional branch, the group III Corona viruses, which are found exclusively in birds. By infecting healthy volunteers, researchers learned that infection with HCoV-229E or HCoV-OC43 results in a common cold, and since then, HCoVs have been considered to be relatively harmless respiratory pathogens. This image was roughly disturbed when severe acute respiratory syndrome (SARS)-CoV was introduced into the human population in the winter of 2002 to 2003 in China. SARS-CoV causes a severe respiratory illness with high morbidity and mortality.

Currently, the Novel Corona Virus disease COVID 19 spreads around the world, killing people and turning them into corpses. The best way to do this in India, that is what it is there are many types of alkaloids in our Indian Medicinal Plants, which kill the virus of any kind and dispose of it. The alkaloids - Piperine, Curcumin, Allicin, Alliin, Allylsulfide, Allyldisulfide, Citric Acid, Acorbic Acid, Menthol, Gingerols, Shogaols, zingerone, oleanolic acid, ursolic acid, rosmarinic acid, eugenol, carvacrol, linalool, $\beta$-caryophyllene etc., the alkaloids that are mentioned are not only killing the virus but also stimulate, and activate the immune system in the body and at the same develops human energy to fight against COVID 19. The preparation and methodologies of simple medicine briefly explained in the topic Novel Remedial Approaches against Virulent Corona Viruses.
\end{abstract}

\section{Introduction}

Corona viruses were first discovered in the 1930 s when an acute respiratory infection of domesticated chickens was shown to be caused by infectious bronchitis virus (IBV). In the 1940s, two more animal Corona viruses, mouse hepatitis virus (MHV) and transmissible gastroenteritis virus (TGEV), were isolated.

Human Corona viruses were discovered in the 1960s [1-9]. The earliest ones studied were from human patients with the common cold, which were later named human Corona virus $229 \mathrm{E}$ and human Corona virus OC43. Other human Corona viruses have since been identified, including SARS-CoV in
2003, HCoV NL63 in 2004, HKU1 in 2005, MERS-CoV in 2012, and SARS-CoV-2 in 2019. Most of these have involved serious respiratory tract infections. The following are the types of Corona viruses:

\section{Types of Human Corona virus}

Corona viruses are named for the crown-like spikes on their surface. There are four main sub-groupings of Corona viruses, known as alpha, beta, gamma, and delta. Human Corona viruses were first identified in the mid-1960s. The seven Corona viruses that can infect people are: 
Common human Corona viruses

1. 229E (alpha corona virus)

2. NL63 (alpha corona virus)

3. OC43 (beta corona virus)

4. HKU1 (beta corona virus)

Other Human Corona Viruses

1. MERS-CoV (the beta corona virus that causes Middle East Respiratory Syndrome, or MERS)

2. SARS-CoV (the beta corona virus that causes severe acute respiratory syndrome)

3. SARS-CoV-2 (the novel corona virus that causes corona virus disease 2019)

People around the world commonly are infected with human coronaviruses 229E, NL63, OC43, and HKU1. Sometimes coronaviruses that infect animals can evolve and make people sick and become a new human corona virus. 3 recent examples of this are 2019-n CoV, SARS-CoV, and MERS-CoV.

\section{Outbreaks of Corona Virus Diseases}

Severe Acute Respiratory Syndrome (SARS)

In 2003, following the outbreak of severe acute respiratory syndrome (SARS) which had begun the prior year in Asia, and secondary cases elsewhere in the world, the World Health Organization (WHO) issued a press release stating that a novel corona virus identified by a number of laboratories was the causative agent for SARS. The virus was officially named the SARS corona virus (SARS-CoV). More than 8,000 people were infected, about ten percent of whom died.

\section{Middle East Respiratory Syndrome (MERS)}

In September 2012, a new type of corona virus was identified, initially called Novel Corona virus 2012, and now officially named Middle East respiratory syndrome corona virus (MERS-CoV). The World Health Organization issued a global alert soon after. The WHO update on 28 September 2012 said the virus did not seem to pass easily from person to person. However, on 12 May 2013, a case of human-to-human transmission in France was confirmed by the French Ministry of Social Affairs and Health. In addition, cases of human-tohuman transmission were reported by the Ministry of Health in Tunisia. Two confirmed cases involved people who seemed to have caught the disease from their late father, who became ill after a visit to Qatar and Saudi Arabia. Despite this, it appears the virus had trouble spreading from human to human, as most individuals who are infected do not transmit the virus. By 30 October 2013, there were 124 cases and 52 deaths in Saudi Arabia.

After the Dutch Erasmus Medical Centre sequenced the virus, the virus was given a new name, Human Corona virusErasmus Medical Centre (HCoV-EMC). The final name for the virus is Middle East respiratory syndrome corona virus (MERS-CoV). The only U.S. cases (both survived) were recorded in May 2014.
Republic of Korea, when a man who had traveled to the Middle East, visited four hospitals in the Seoul area to treat his illness. This caused one of the largest outbreaks of MERS-CoV outside the Middle East. As of December 2019, 2,468 cases of MERS$\mathrm{CoV}$ infection had been confirmed by laboratory tests, 851 of which were fatal, a mortality rate of approximately $34.5 \%$.

\section{Corona Virus Disease 2019 (COVID-19)}

In December 2019, a pneumonia outbreak was reported in Wuhan, China. On 31 December 2019, the outbreak was traced to a novel strain of corona virus, which was given the interim name 2019-nCoV by the World Health Organization (WHO), later renamed SARS-CoV-2 by the International Committee on Taxonomy of Viruses. Some researchers have suggested the Huanan Seafood Wholesale Market may not be the original source of viral transmission to humans.

As of 6 April 2020, there have been at least 69,527 confirmed deaths and more than 1,276,302 confirmed cases in the corona virus pneumonia pandemic. The Wuhan strain has been identified as a new strain of Beta corona virus from group 2B with approximately $70 \%$ genetic similarity to the SARS-CoV. The virus has a $96 \%$ similarity to a bat corona virus, so it is widely suspected to originate from bats as well. The pandemic has resulted in travel restrictions and nationwide lockdowns in several countries.

\section{Etymology}

The name "corona virus" is derived from Latin corona, meaning "crown" or "wreath", itself a borrowing from Greek корஸ́vๆ korốnē, "garland, and wreath". The name refers to the characteristic appearance of virions (the infective form of the virus) by electron microscopy, which has a fringe of large, bulbous surface projections creating an image reminiscent of a crown or of a solar corona. This morphology is created by the viral spike peplomers, which are proteins on the surface of the virus.

\section{Morphology of Corona Virus:}

Corona viruses are large pleomorphic spherical particles with bulbous surface projections. The diameter of the virus particles is around $120 \mathrm{~nm}$. The envelope of the virus in electron micrographs appears as a distinct pair of electron dense shells.

The viral envelope consists of a lipid bilayer where the membrane (M), envelope (E) and spike (S) structural proteins are anchored. A subset of corona viruses (specifically the members of beta corona virus subgroup A) also has a shorter spike-like surface protein called hemagglutinin esterase (HE).

Inside the envelope, there is the nucleocapsid, which is formed from multiple copies of the nucleocapsid $(\mathrm{N})$ protein, which are bound to the positive-sense single-stranded RNA genome in a continuous beads-on-a-string type conformation. The lipid bilayer envelope, membrane proteins, and nucleocapsid protect the virus when it is outside the host cell.

In May 2015, an outbreak of MERS-CoV occurred in the 

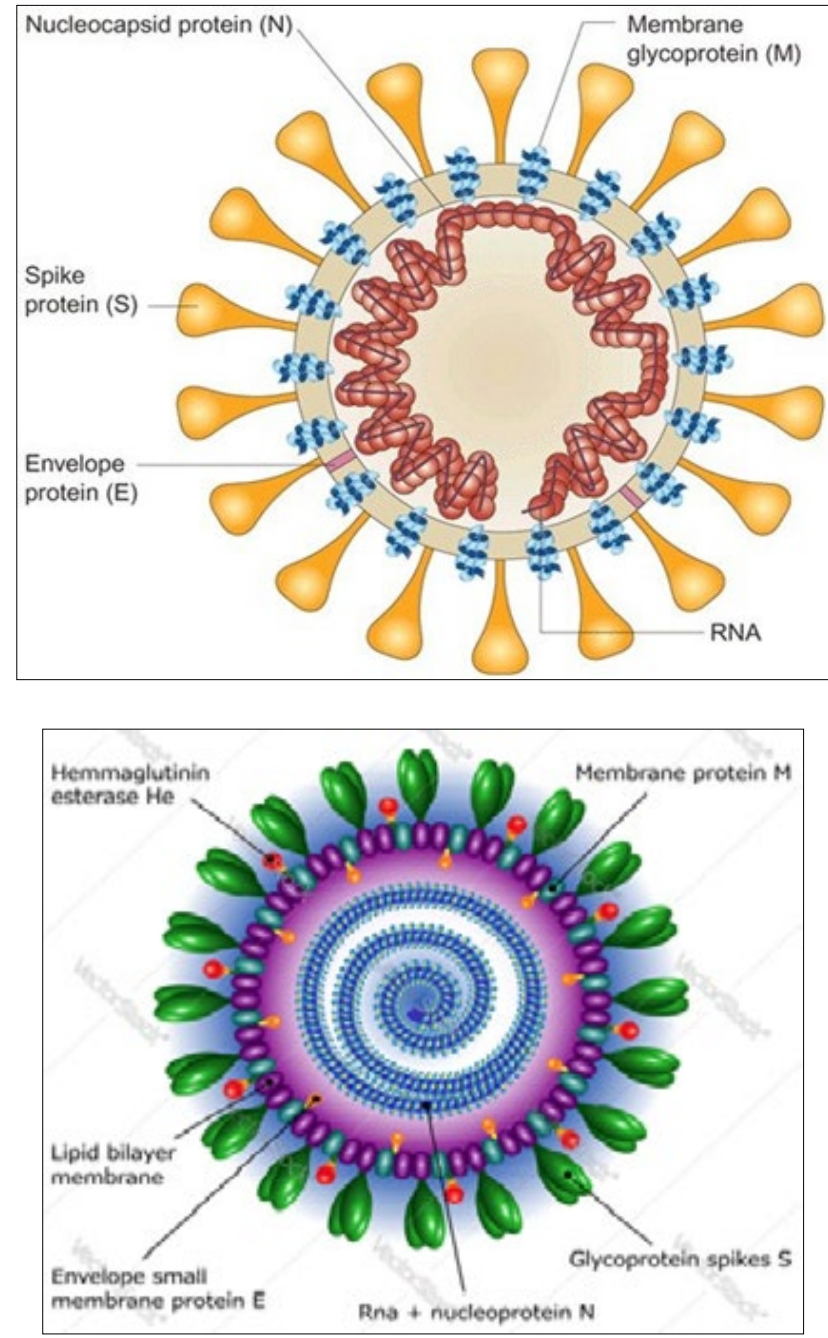

Structure of Corona Virus

Genome

Schematic representation of the genome organization and functional domains of S protein for SARS-CoV and MERS$\mathrm{CoV}$, Corona viruses contain a positive-sense, single-stranded RNA genome. The genome size for corona viruses ranges from approximately 27 to 34 kilobases. The genome size is one of the largest among RNA viruses. The genome has a 5' methylated cap and a $3^{\prime}$ polyadenylated tail. The genome organization for a corona virus is 5'-leader-UTR-replicase/transcriptasespike (S)-envelope (E)-membrane (M)-nucleocapsid (N)3'UTR-poly (A) tail. The open reading frames $1 \mathrm{a}$ and $1 \mathrm{~b}$, which occupy the first two-thirds of the genome, encode the replicase/transcriptase polyprotein. The replicase/transcriptase polyprotein self cleaves to form nonstructural proteins. The later reading frames encode the four major structural proteins: spike, envelope, membrane, and nucleocapsid. Interspersed between these reading frames are the reading frames for the accessory proteins. The number of accessory proteins and their function is unique depending on the specific corona virus [10$18]$.

\section{Incubation period of Corona Virus}

Mean incubation period 5-6 days, range 1-14 days

\section{Pathogenesis}

Studies in both organ cultures and human volunteers show that corona viruses are extremely fastidious and grow only in differentiated respiratory epithelial cells. Infected cells become vacuolated, show damaged cilia, and may form syncytia. Cell damage triggers the production of inflammatory mediators, which increase nasal secretion and cause local inflammation and swelling. These responses in turn stimulate sneezing, obstruct the airway, and raise the temperature of the mucosa.

\section{Life Cycle of Corona virus}

\section{Entry}

Infection begins when the viral spike (S) glycoprotein attaches to its complementary host cell receptor. After attachment, a protease of the host cell cleaves and activates the receptorattached spike protein. Depending on the host cell protease available, cleavage and activation allows the virus to enter the host cell by endocytosis or direct fusion of the viral envelop with the host membrane.

On entry into the host cell, the virus particle is uncoated, and its genome enters the cell cytoplasm. The corona virus RNA genome has a $5^{\prime}$ methylated cap and a $3^{\prime}$ polyadenylated tail, which allows the RNA to attach to the host cell's ribosome for translation. The host ribosome translates the initial overlapping open reading frame of the virus genome and forms a long polyprotein. The polyprotein has its own proteases which cleave the polyprotein into multiple nonstructural proteins.

\section{Corona virus Replication}

1. With their S-Protein, corona viruses blind on cell surface molecules such as the metalloproteaseamino-peptidase $\mathrm{N}$. Viruses, which accessorily have the HE-protein, can also blind on $\mathrm{N}$-acetylneuraminic acid that serves as a coreceptor.

2. So far, it is not clear whether the virus get into the host cell by fusion of viral and cell membrane or by receptor mediated endocytosis in that the virus is in-corporated via an endosome, which is subsequently acidified by proton pumps, in that case, the virus have to escape destruction and transport to the lysosome.

3. Since coronaviruses have a single positive stranded RNA genome, they can directly produce their proteins and new genomes in the cytoplasm. At first, the virus synthesizes the minus strand using the positive strand as template.

4. Subsequently, this negative strand serves as template to transcribe smaller sub genomic positive RNAs which are use to synthesize all other proteins. Furthermore, this negative strand serves for replication of new positive stranded RNA genomes.

5. The protein $\mathrm{N}$ binds genomic RNA and the protein $\mathrm{M}$ is integrated into the membrance of the endoplasmatic reticulum (ER) like the envelop proteins $\mathrm{S}$ and HE. After binding assembled nucleocapsids with helical twisted RNA budd into the ER lumen and are encased with its membrane.

6. These viral progeny are finally transported by Golgi 
vesicles to the cell membrane and are exocytose into the extracellular space.

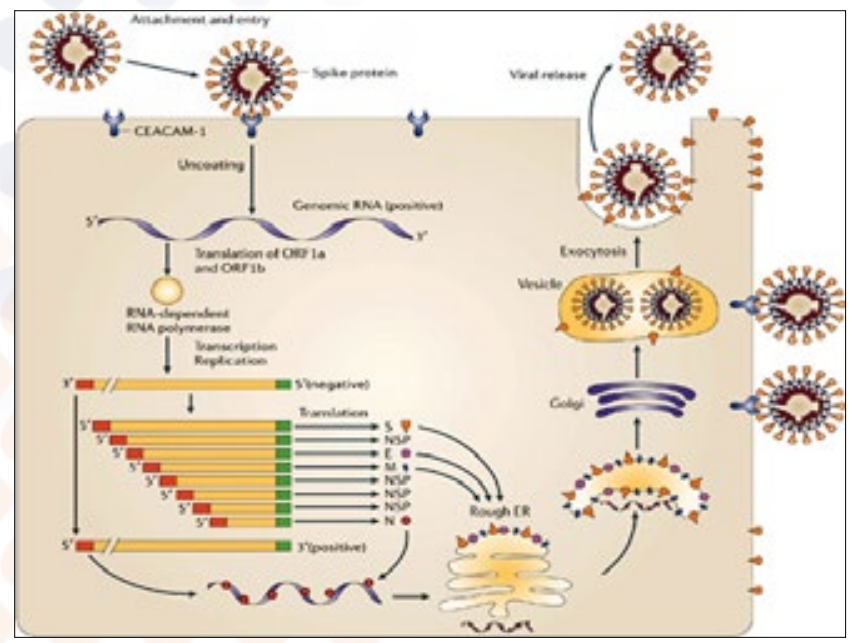

A number of the nonstructural proteins coalesce to form a multi-protein replicase-transcriptase complex (RTC). The main replicase-transcriptase protein is the RNA-dependent RNA polymerase (RdRp). It is directly involved in the replication and transcription of RNA from an RNA strand. The other nonstructural proteins in the complex assist in the replication and transcription process. The exoribonuclease nonstructural protein, for instance, provides extra fidelity to replication by providing a proofreading function which the RNA-dependent RNA polymerase lacks.

One of the main functions of the complex is to replicate the viral genome. RdRp directly mediates the synthesis of negative-sense genomic RNA from the positive-sense genomic RNA. This is followed by the replication of positivesense genomic RNA from the negative-sense genomic RNA. The other important function of the complex is to transcribe the viral genome. RdRp directly mediates the synthesis of negative-sense sub genomic RNA molecules from the positivesense genomic RNA. This is followed by the transcription of these negative-sense sub genomic RNA molecules to their corresponding positive-sense mRNAs.

\section{Release}

The replicated positive-sense genomic RNA becomes the genome of the progeny viruses. The mRNAs are gene transcripts of the last third of the virus genome after the initial overlapping reading frame. These mRNAs are translated by the host's ribosomes into the structural proteins and a number of accessory proteins. RNA translation occurs inside the endoplasmic reticulum. The viral structural proteins $\mathrm{S}$, $\mathrm{E}$, and $\mathrm{M}$ move along the secretory pathway into the Golgi intermediate compartment. There, the $\mathrm{M}$ proteins direct most protein-protein interactions required for assembly of viruses following its binding to the nucleocapsid. Progeny viruses are then released from the host cell by exocytosis through secretory vesicles.

\section{Transmission}

The interaction of the corona virus spike protein with its complement host cell receptor is central in determining the tissue tropism, infectivity, and species range of the virus. The SARS corona virus, for example, infects human cells by attaching to the angiotensin-converting enzyme 2 (ACE2) receptor.

\section{Signs and Symptoms}

People may be sick with the virus for 1 to 14 days before developing symptoms. The most common symptoms of corona virus disease (COVID-19) are fever, tiredness, and dry cough. Most people (about 80\%) recover from the disease without needing special treatment.

More rarely, the disease can be serious and even fatal. Older people, and people with other medical conditions (such as asthma, diabetes, or heart disease), may be more vulnerable to becoming severely ill.

\author{
People may Experience: \\ 1. Cough \\ 2. Fever \\ 3. Tiredness \\ 4. Difficulty in breathing (severe cases) \\ 5. Sore throat (Throat Pain) \\ 6. Conjunctivitis \\ 7. Diarrhea
}

\section{Treatment}

There is no specific medicine to prevent or treat corona virus disease (COVID-19). People may need supportive care to help them breathe.

\section{Self-care}

If you have mild symptoms, stay at home until you've recovered. You can relieve your symptoms if you: Rest and sleep, Keep warm, Drink plenty of liquids, Use a room humidifier or take a hot shower to help ease a sore throat and cough

\section{Medical Treatments}

If you develop a fever, cough, and have difficulty breathing, promptly seek medical care. However, many of the symptoms can be treated and therefore treatment based on the patient's clinical condition. Many clinical practitioners obtain positive response with Hydroxychloroquine and Azithromycin in the cases of corona positive. While all this is happening, there is still no scientific evidence that proves hydroxychloroquine is indeed the answer to the Corona virus. It may very well be, but there is still no medical evidence to show that it indeed works. The medical professionals and the research workers are deeply indulge in clinical trials.

Chloroquine phosphate is a class of drugs called antimalarials and amebicides and is used to prevent and treat malaria. They add that Chloroquine phosphate is used occasionally to decrease the symptoms of rheumatoid arthritis and to treat systemic and discoid lupus erythematosus, scleroderma, pemphigus, lichen planus, polymyositis, sarcoidosis, and porphyria cutanea tarda. Governments believe that hydroxychloroquine tablets 
can work as a prophylactic, a medicine that prevents disease, for the health workers working on the frontlines in hospitals and as first responders to possible Corona virus infection cases. The antimalarial drug, hydroxychloroquine, is licensed for the chemoprophylaxis and treatment of malaria and as a disease-modifying antirheumatic drug. It has a history of being safe and well tolerated at typical doses. Notably, the drug shows antiviral activity in vitro against corona viruses, and specifically, SARS-CoV-2.

\section{Antiviral Drugs Used in Corona Virus}

In order to replicate, an RNA virus needs to make more copies of its RNA genome. This means antiviral drugs which block the copying of RNA genomes can potentially help treat COVID-19 patients. These drugs are known as RNApolymerase inhibitors.

Remdesivir is also effective against other RNA viruses including Ebola virus and the coronaviruses SARS and Middle Eastern respiratory syndrome (MERS).

Scientists are currently assessing remdesivir in clinical trials in the United States and China. Time will tell if remdesivir is effective for COVID-19 patients. But doctors are already considering how the drug is best administered for optimal results and whether it should be used in combination with other drugs or as a single agent.

The National Medical Products Administration of China has approved the use of Favilavir, an anti-viral drug, as a treatment for corona virus. The drug has reportedly shown efficacy in treating the disease with minimal side effects in a clinical trial involving 70 patients. The clinical trial is being conducted in Shenzhen, Guangdong province.

Scientists are hopeful that a new drug -- called EIDD-2801 -- could change the way doctors treat COVID-19. The drug shows promise in reducing lung damage, has finished testing in mice and will soon move to human clinical trials.

\section{Recovery Time for the Corona Virus Disease}

Using available preliminary data, the median time from onset to clinical recovery for mild cases is approximately 2 weeks and is 3-6 weeks for patients with severe or critical disease.

What Happens to the Human Lungs When they Get Covid-19 The cause of the pneumonia was found to be a new virus severe acute respiratory syndrome corona virus 2, or SarsCoV-2. The illness caused by the virus is Covid-19. Now declared as a pandemic by the World Health Organization (WHO), the majority of people who contract Covid-19 suffer only mild, cold-like symptoms. $80 \%$ of people with Covid-19 recover without needing any specialist treatment. Only about one person in six becomes seriously ill and develops shortness of breathing.

When people with Covid-19 develop a cough and fever, Wilson says this is a result of the infection reaching the respiratory tree - the air passages that conduct air between the lungs and the outside. The lining of the respiratory tree becomes injured, causing inflammation. This in turn irritates the nerves in the lining of the airway. Just a speck of dust can stimulate a cough, but if this gets worse, it goes past just the lining of the airway and goes to the gas exchange units, which are at the end of the air passages. If they become infected they respond by pouring out inflammatory material into the air sacs that are at the bottom of our lungs. If the air sacs then become inflamed, Wilson says this causes an "outpouring of inflammatory material [fluid and inflammatory cells] into the lungs and we end up with pneumonia. The lungs that become filled with inflammatory material are unable to get enough oxygen to the bloodstream, reducing the body's ability to take on oxygen and get rid of carbon dioxide. That's the usual cause of death with severe pneumonia.

Novel Remedial Approaches against Virullent Corona Viruses

Nutrition oriented Immunotherapy is the treatment of Corona Virus by using therapies to stimulate or suppress the body's immune system to fight Corona Virus. As we know the several distinct modalities of immunotherapy exist, including cytokines, vaccines, viruses, adoptive cell transfer, and checkpoint blockade using monoclonal antibodies. The nutrition oriented immunotherapy shows promising effective and efficient results in the people who infected by Covid-19.

\section{Black Pepper}

Black pepper (Piper nigrum L) contains a bioactive phytochemical, piperine (Figure 4), that exhibits many physiological and pharmacological properties including antioxidant, anti-inflammatory, antimutagenic, antitumor, antiapoptotic, antigenotoxic, antiarthritic, antifungal, antidepresseant, anti-HVB (hepatitis B) and gastro-protective activities. Piperine also enhances the bioavailability of phytochemicals (e.g., curcumin) and drugs. Piperine inhibits free radicals and reactive oxygen species and lipid peroxidation due to their flavonoids and phenolic contents. The antioxidant activity of black pepper was evaluated through the determination of gluthathione peroxidase, catalase, superoxide dismutase including measurement of reduced glutathione content and the amount of malondialdehyde, and protein carbonyl levels in the hippocampus.

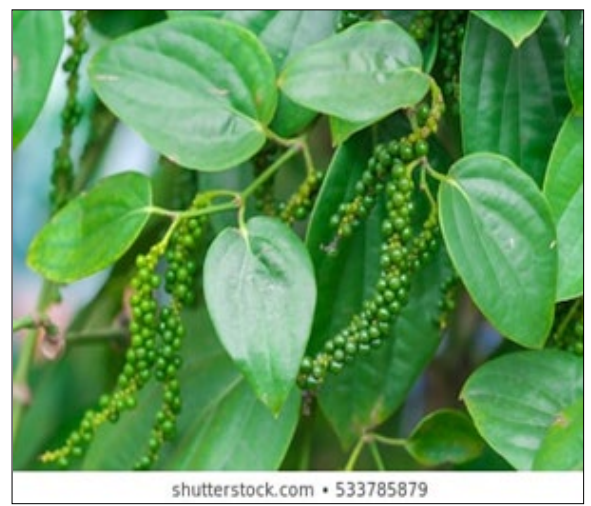




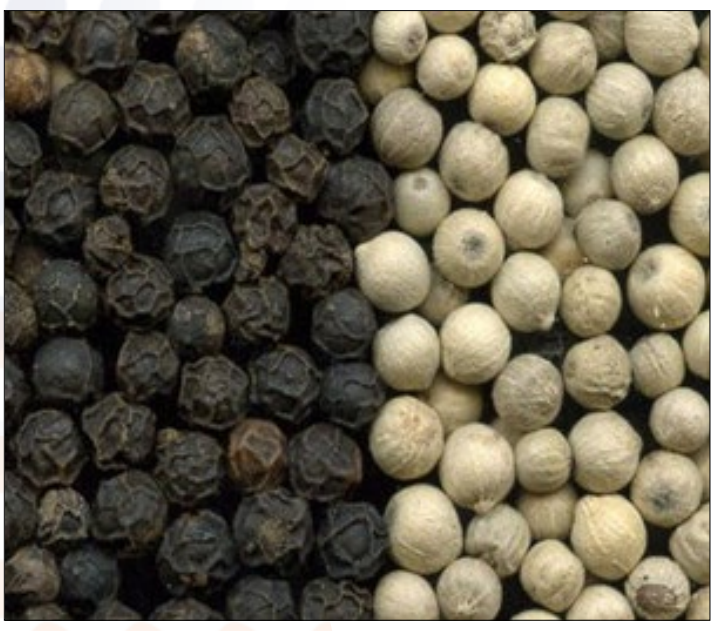

IMAGES OF PIPER NIGRUM (BLACK PEPPER)

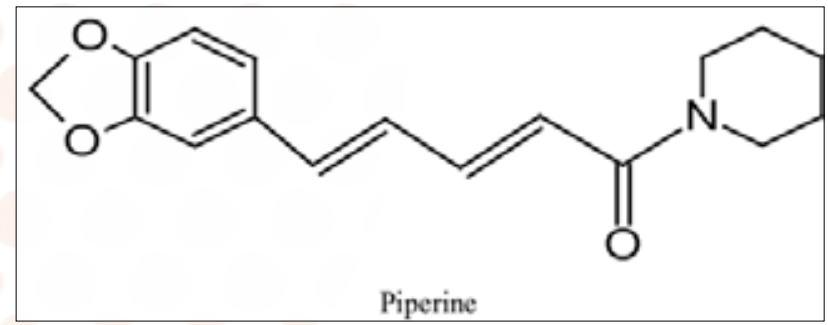

Molecular Structure of Piperine

\section{Piper Longum}

It is most commonly used to treat chronic bronchitis, asthma, constipation, gonorrhea, paralysis of the tongue, diarrhea, cholera, chronic malaria, viral hepatitis, respiratory infections, stomachache, and bronchitis, diseases of the spleen, cough, and tumors.

Piper longum (family Pipperaceae) is used as an important traditional medicine in Asia and the Pacific islands. Piper longum has been reported as a good remedy for treating tuberculosis and respiratory tract infections [19]. The fruits and roots of this plant have been used in the treatment of childhood asthma [20, 21]. The alcoholic extract of P. longum fruits showed immunomodulatory potential in experimental animal studies [22]. Piperine is a major alkaloid isolated from the P. longum fruits and has been reported to inhibit the release of Th-2-mediated cytokines, eosinophil infiltration, and airway hyper-responsiveness in an ovalbumin-induced asthma model [23].

However, an active ingredient present in long pepper, piperine, combined with rifampicin, effectively inhibited rifampicinresistant mutant strains. Piperine also caused an increase in the bioavailability of drugs like phenytoin, propranolol, and theophylline in healthy volunteers. Taking inspiration from Ayurvedic practice and its knowledge of Trikatu, scientists have developed the revolutionary category of bioenhancers. This is one of the best examples of reverse pharmacology approach.
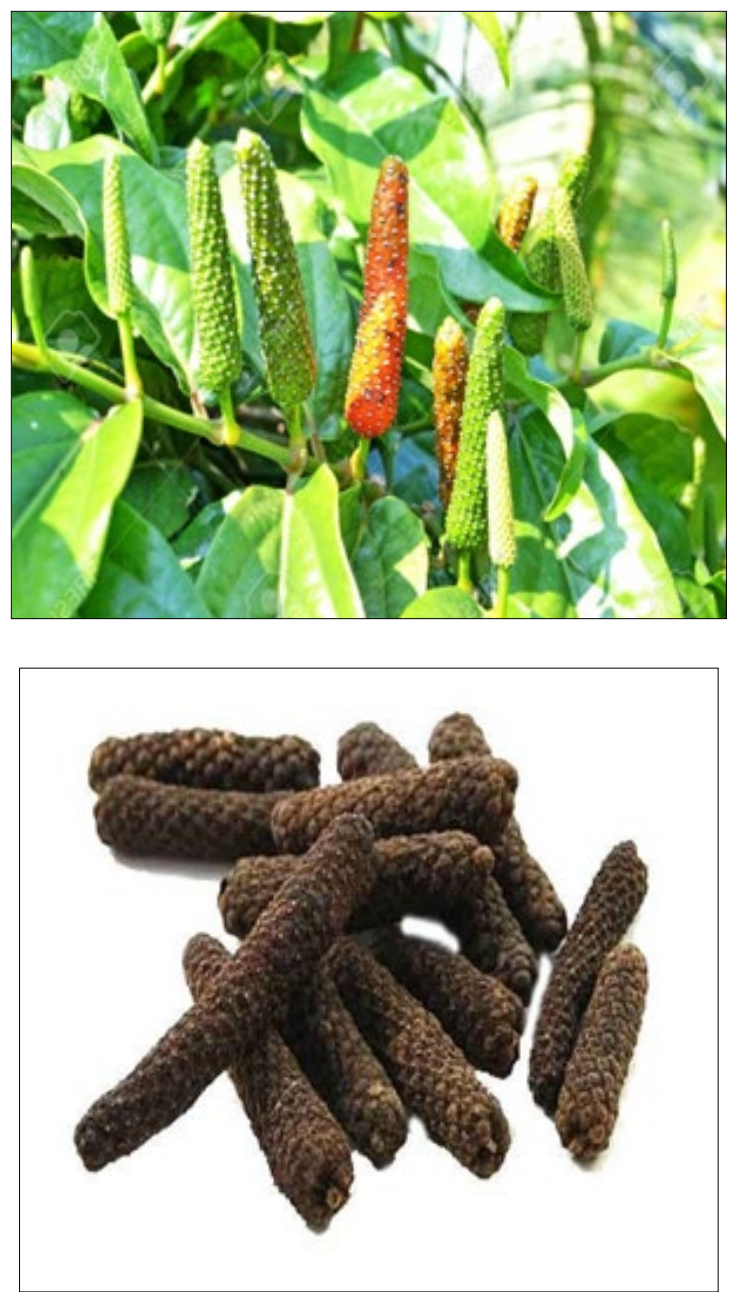

Images of Piper Longum Plant (Long Black Pepper)

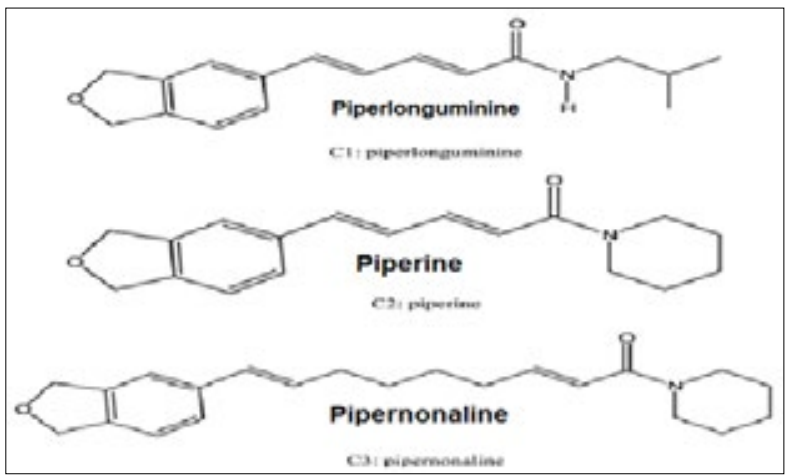

Chemical Structures of Piperlongum (Long Pepper)

Garlic (Allium sativum L. family Liliaceae) is well known in Iran and its leaves, flowers, and cloves have been used in traditional medicine for a long time. Research in recent decades has shown widespread pharmacological effects of A. sativum and its organosulfur compounds especially Allicin. Studies carried out on the chemical composition of the plant show that the most important constituents of this plant are organosulfur compounds such as allicin, diallyl disulphide, S-allylcysteine, and diallyl trisulfide. Allicin represents one of the most studied among these naturally occurring compounds. 
Antibacterial - Staphylococcus aureus, Escherichia coli, Salmonella typhi, Bacillus subtilis, Klebsiella pneumaniae, Helicobacter pylori, Sal enteritidis, Shigella sp, Proeus mirabilis, Actinobacillus pleura pneumonia serotype 9, and Streptococcus mutan.

Antiviral - Human Cyto Megalo Virus(HCMV), Influenza B, Herpes simplex virus type 1-2, Para influenza virus type 3, Vaccine Virus, Vesicular Stomatitis virus, Human rhino virus type 2

Antifungal - Caandida albicans, C. tropicalis, Blastoschizomyces capitatus, Botr. Cinerea, Trichoderma harzianum, Ascospaera apis, Paracoccidioides brasiliensis, Aspergillus niger, Dermatophytes, Saprophytes, Cryptococcal, Botr Cinerea Mycosphaerella, Arachidicola, and Physalospara piricola

Anti-Parasitic - Trypanosoma sp, Entamoeba histolytica, Giardia lamblia, Trypa Cruzi, Plasmodium spp, Giardia spp, Leishmania spp, Cochlospermum planchomi, Hymenolepiasis, Giardiasis, and Haemonchus contortus

Cardiovascular - Hypertensive via increasing nitric oxide synthesis, Hypertensive (Endothelial dependent and independent), Induces Vasodilatation with $\mathrm{H} 2 \mathrm{~S}$, Angiotenin Converting Enzyme inhibiting activity, Stimulation of nitric oxide generation in endothelial cells, Bradycardia, Hepatopulmonary syndrome, Decreases systolic blood pressure, Vasorelaxant, Coronary Artery Disease, Reduce Myocardial Infarction, Stroke, Anti-thrombotic, and Antiatherosclerotic

Blood - Hypolipemic effect, Hypocholesterolemic, Hypotriglycede, and Hypoglycemic,

Immune-System - Immunomodulation, Anti-inflammatory and Anti-Oxidant Properties

\section{Antiviral Mechanism with garlic cloves}

A. sativum has been shown to have antiviral activity. In one study the virucidal activity of this plant was attributed to the following contents in this order: ajoene $>$ allicin $>$ allyl methyl $>$ thiosulfinate $>$ methyl allyl thiosulfinate. Also Allicin, the main constituent of A. sativum, has a variety of antimicrobial activities both in vitro and in vivo. Among the viruses which are sensitive to garlic extracts are the human Cytomegalovirus (HCMV), influenza B virus, Herpes simplex virus type 1 , Herpes simplex virus type 2, Para influenza virus type 3, vaccinia virus, vesicular stomatitis virus, and human Rhinovirus type 2. One study showed that Allicin-containing supplements can prevent attacks by the common cold virus. The main antimicrobial effect of Allicin is due to its chemical reaction with thiol groups of various enzymes, e.g. alcohol dehydrogenase. In an In vivo study the administration of garlic in mice models protected them against. Intranasal inoculation with influenza viruses and enhanced the production of neutralizing antibodies when given the vaccine.
Ajoene, isolated from extracts of garlic may inhibit adhesive interaction and fusion of leukocytes. In a study investigating the effect of Allitridin (diallyl trisulfide, a compound from A. sativum extraction) on the replication of HCMV and the expression of viral immediate-early genes, it was revealed that this substance has anti-HCMV efficacy. In another study, it was supposed that the antiviral activity of garlic in humans may be secondary to a direct toxic effect on viruses. It also enhanced NK-cell (Natural killer-cell) activity that destroys virus-infected cells.
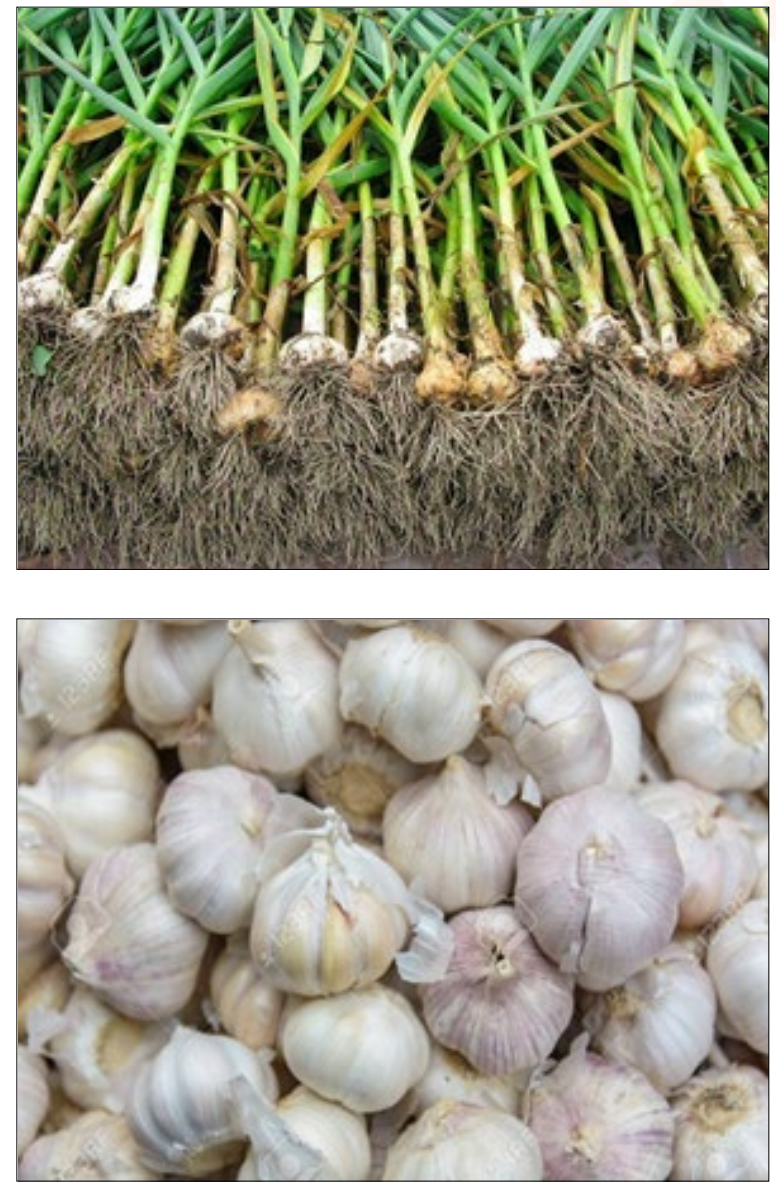

Images of Allium Setivum (Garlic) Plant

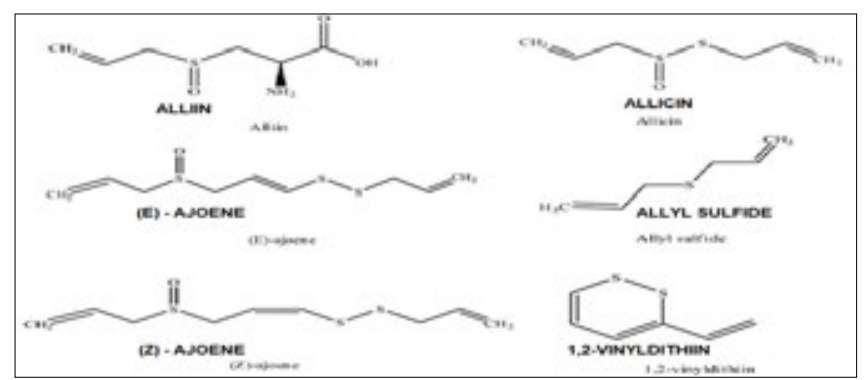

Chemical structures of Garlic

Ginger (Zingiber Officinale) Prevents Severe Damage to the Lungs Due to Hyperoxia and Inflammation

Ginger efficiently reduced the lung damage and protected the lungs from severe damage due to hyperoxia and inflammation. Therefore, ginger may be an alternative option for the treatment 
of BPD. Ginger helps to break down mucus, making it easier for your body to expel air. It also helps improve circulation to the lungs and reduces inflammation.

Ginger is a bronchodilator - The study, which tested the effects of ginger components on isolated human airway cells, found ginger worked particularly well in combination with a medication currently used in bronchodilators asthmatics carry in case they have trouble breathing. Ginger and its active components induce bronchodilation by modulating intracellular calcium $[\mathrm{Ca} 2+]$ in airway smooth muscle (ASM).

In isolated human ASM, ginger caused significant and rapid relaxation. Ginger boosts the immune system. This includes common colds, the flu, and mononucleosis. Ginger stimulates the immune system to kill viruses and has the potential to reduce incidences of sore throat, provide quicker symptom relief, and improve recovery time.

Ginger has been shown to have impressive antiviral activity thanks to its high concentration of potent plant compounds. Additionally, specific compounds in ginger, such as gingerols and zingerone, have been found to inhibit viral replication and prevent viruses from entering host cells.
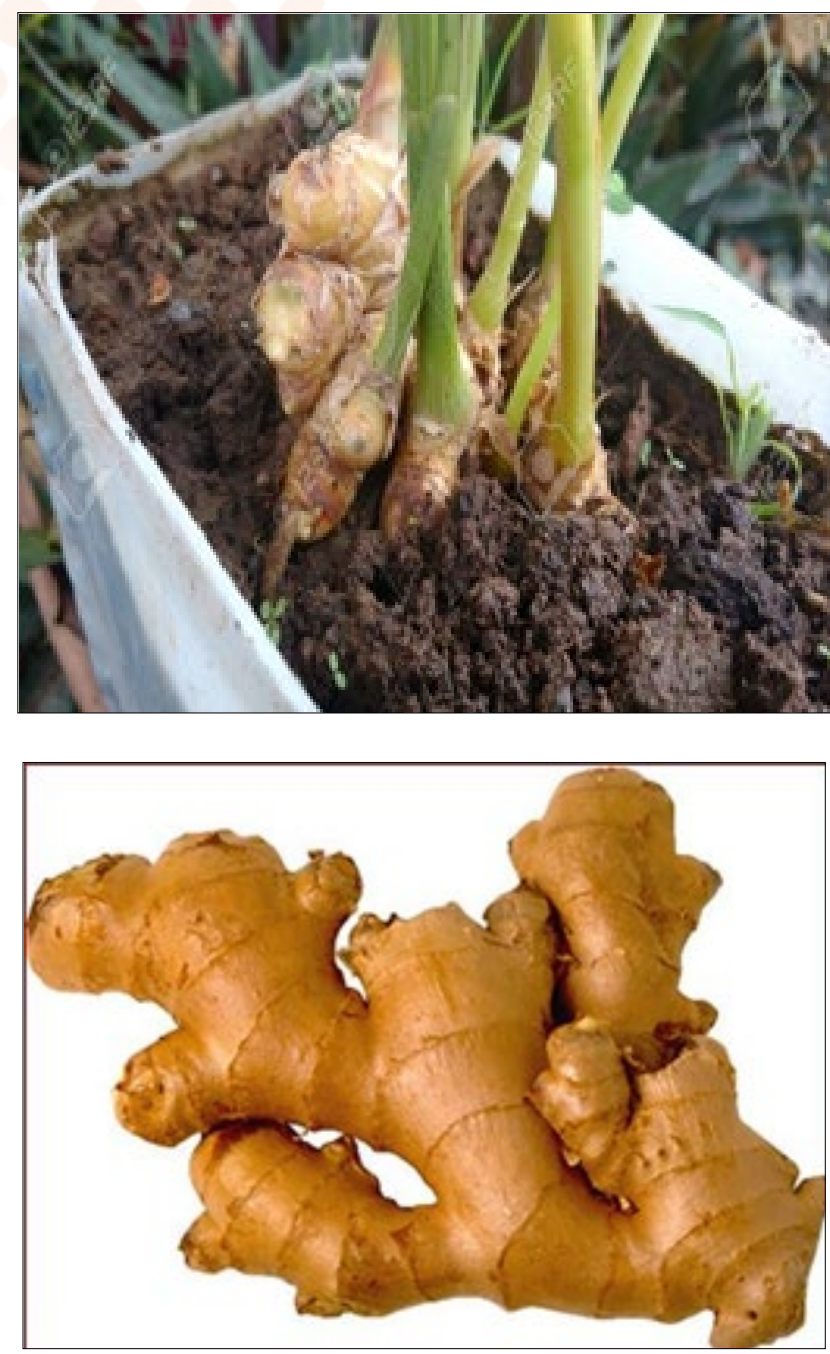

Images of Gingiber Officinale Plant (Ginger)
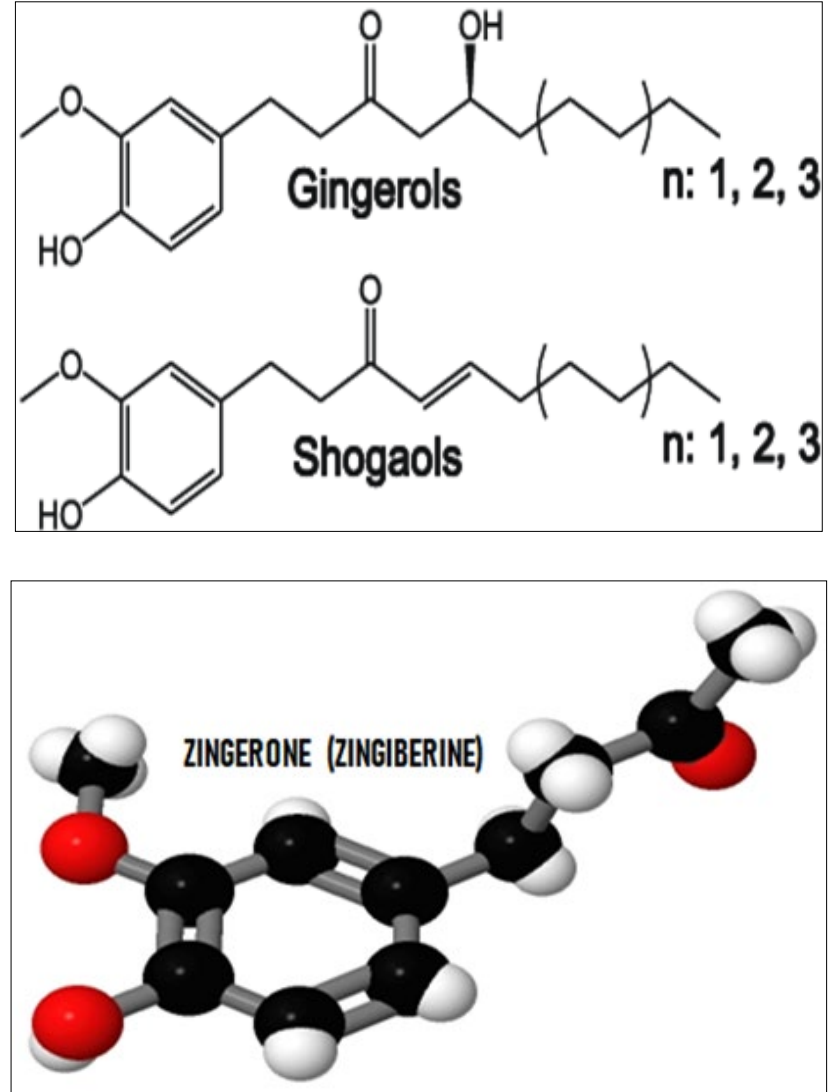

Molecular Structure of Gingerols and Shogaols

\section{Curcuma longa}

Curcuma longa L. (Zingiberaceae), commonly known as turmeric, is native to Southwest India with its rhizomes being the source of a bright yellow spice with various medicinal applications. It is widely cultivated throughout the tropics and similarly used for it medicinal value, in the cosmetic industry, and as a dye. Herein, the medicinal potentials of this plant as well as that of one of its bioactive constituents, curcumin, have been compiled. Turmeric can be regarded as a drug for the management of many diseases, such as cancer, inflammations, microbial infections, diabetes, arthritic, muscular disorders, biliary disorders, anorexia, cough, diabetic wounds, hepatic disorders, and sinusitis. Curcumin also displayed various pharmacological activities including antioxidant, antineoplastic, antiviral, antiinflammatory, antibacterial, antifungal, antidiabetic, anticoagulant, antifertility, cardiovascular protective, hepatoprotective, and immunostimulant activities in animals. Both turmeric and curcumin, the active ingredient in turmeric supplements, have anti-inflammatory, antioxidant, antibacterial, antiviral and antiparasitic activity.

Several studies have reported that curcumin exhibits an antiHIV activity by directly targeting viral proteins. Curcumin's biological effects are as wide ranging as its molecular targets. The main benefits for the liver include its antiinflammatory, anticancer, antifibrotic, antiviral, antiheavy metals, and antisteatotic properties. A brief summary of the beneficial actions of curcumin is discussed below. 
Turmeric antiinflammatory activity: Inflammation is part of a complex biological response that is induced by harmful stimulation, such as burns, pathogens, and chemical irritants. Curcumin has been shown to inhibit a number of different molecules involved in inflammation including the nuclear transcription factor kappa B (NFкB), MAPK, cyclooxygenase (COX), lypossigenase (LOX), prostaglandins, NO, collagenase, elastase, hyaluronidase, MCP-1, interferoninducible protein, and is able to down regulate the secretion of prominent cytokines, like TNF $\alpha$, IL- $1 \beta$, and IL- 6 , and to block the expression of cell adhesion molecules, which are necessary for the interaction of leukocytes with endothelial cells.

Turmeric antioxidant activity: Curcumin is a good antioxidant and inhibits lipid peroxidation, so helping to protect against atherosclerosis. It acts as a scavenger of oxygen-free radicals. Curcumin and its three derivatives (demethoxy curcumin, bisdemethoxy curcumin, and diacethyl curcumin) protect haemoglobin from oxidation. The effect of curcumin on lipid peroxidation has also been studied in various models by several authors. The antioxidant activities of turmeric are not degraded by heat (unlike most vitamins), therefore using the spice in cooking provides benefits.
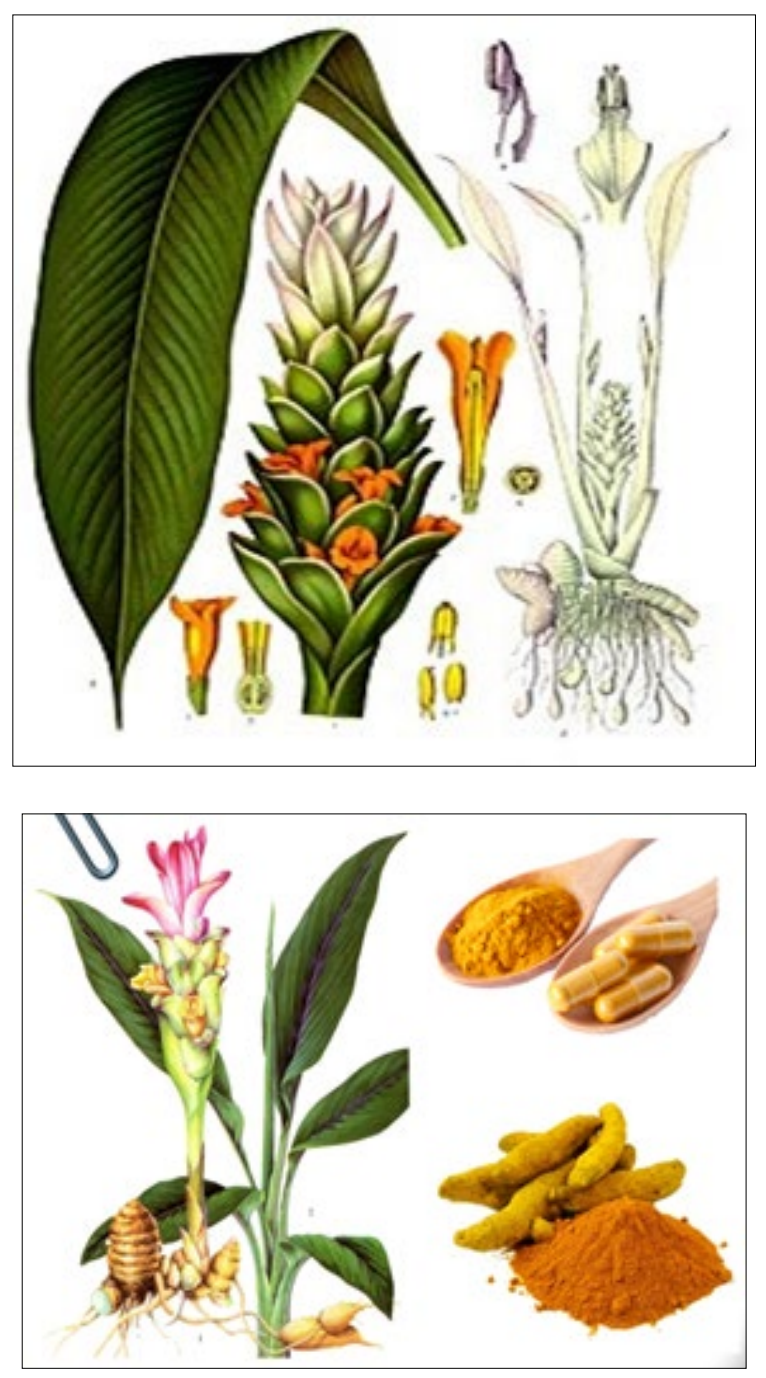

Images of Curcuma Longa Plant

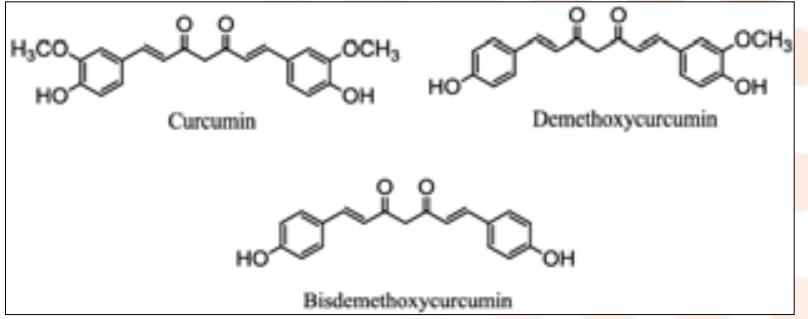

Demethoxycurcumin and Bisdemethoxycurcumin

\section{Citrus Lemon}

The majority of chemical compounds in lemon fruits are alkaloids. Three important chemicals in lemon juice are water, citric acid and carboxylic acid [24, 25]. The bioactive compounds contained in lemon (Citrus limon) each have an antibacterial. Lemon (Citrus aurantifolia) juice besides being used as an antibacterial, it is also useful as an antioxidant. The main content of lemon (Citrus limon) juice is vitamin $\mathrm{C}$ and citric acid.

Lemon has many bioactive components such as citric acid, Ascorbic acid, minerals, flavonoids and essential oils [5]. Citrus essential oils are generally recognized as safe (GRAS) and a complex mixture of about 400 constituents consisting of $85-99 \%$ volatile and $1-15 \%$ non-volatile components [6].

Lemon is used to treat scurvy, a condition caused by not having enough vitamin C. Lemon is also used for the common cold and flu, H1N1 (swine) flu, ringing in the ears (tinnitus), Meniere's disease, stomach upset and vomiting from pregnancy, and kidney stones. It is also used to aid digestion, reduce hay fever symptoms, reduce pain and swelling (inflammation), lower blood pressure, improve the function of blood vessels, and increase urination to reduce fluid retention.

Lemon juice can be used in cooking, baking, making beverages, and cleaning items around the home. Lemon contains significant amounts of citric acid, which accounts for its immune-boosting, antibacterial, and antiviral properties. Drinking lemon juice can help improve kidney and heart health and can aid in weight loss, too. The oil from lemon peel is often used in furniture polish, detergent, soaps, perfumes, and other body care products. The dehydrated peel from a lemon is often used in cattle feed. While lemon is generally thought to be safe, excessive consumption can result in tooth erosion due to its acidic content.

\section{How does it work?}

Lemon contains antioxidants called bioflavonoids. Researchers think these bioflavonoids are responsible for the health benefits of lemon.

\section{Uses \& Effectiveness}

- Allergies (hay fever): Results from a small study show that using a nasal spray containing lemon and quince doesn't improve allergy symptoms.

- High blood pressure: Middle-aged women who drink more lemon juice or eat more lemons seem to have lower 
systolic blood pressure (the top number). They don't seem to have lower diastolic blood pressure (the bottom number).

- Meniere's disease: There are some reports that a chemical in lemon might improve hearing and decrease dizziness, nausea, and vomiting in some people with Meniere's disease.

- Kidney stones: Not having enough citrate in the urine seems to increase the risk of developing kidney stones. There is some evidence that drinking 2 liters of lemonade throughout the day can significantly raise citrate levels in the urine. This might help to prevent kidney stones in these people.

- Pregnancy-induced nausea and vomiting: A small study shows that placing lemon essential oil on a cotton ball and inhaling the scent might reduce nausea in pregnant women.

- Radiation exposure: Early research in people with thyroid cancer shows that aromatherapy baths with lemon and ginger essential oils can reduce damage inside the mouth from radioactive iodine treatment.

- Common cold, Decreasing swelling, Flu, Increasing urine, Scurvy

- Other conditions.
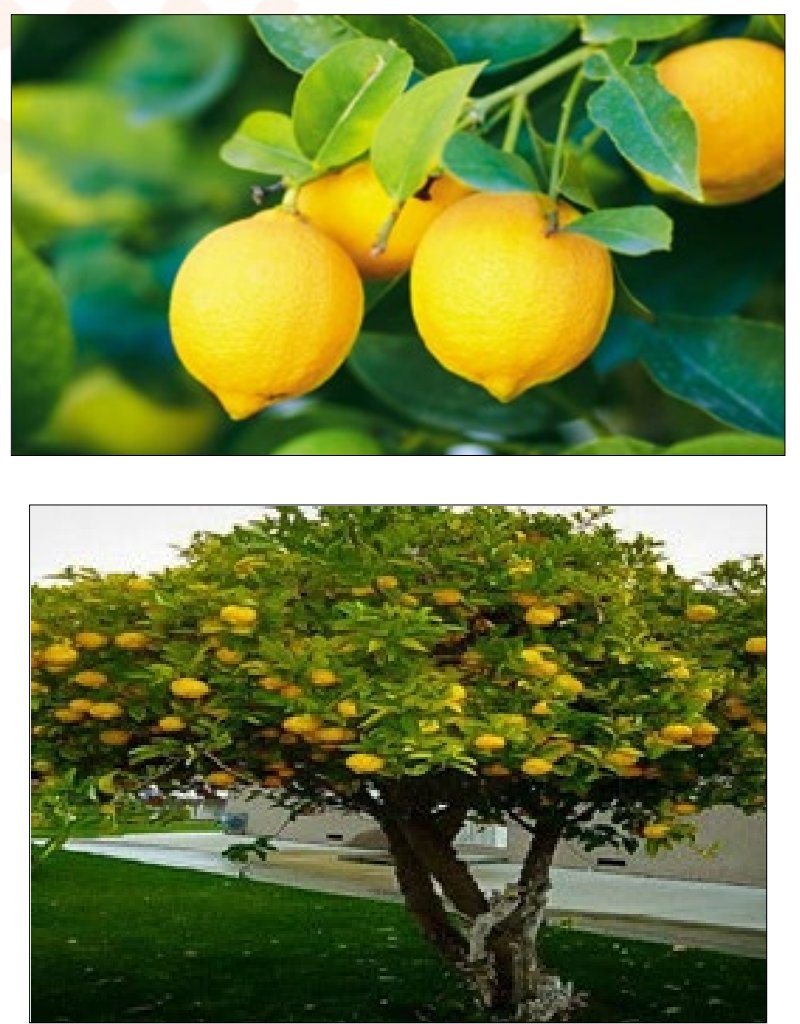

Images of Citrus Lemon Plant
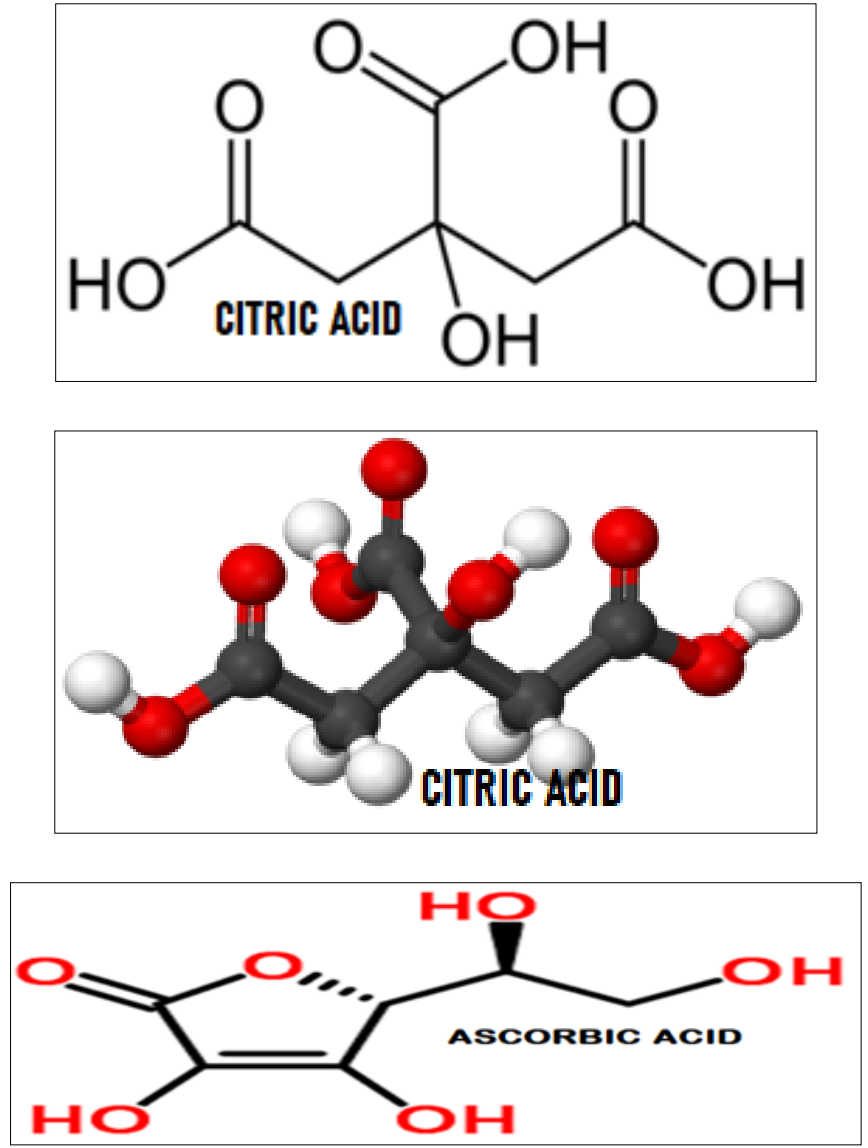

Molecular Structure of Citric Acid

Tulasi/Ocimum Sactum/Holy Basil

In vitro antiviral potential of Ocimum sanctum leaves extract against New Castle Disease Virus of poultry, Ocimum sanctum is well known for its antimicrobial properties in Indian traditional medicinal system in Ayurveda. Tulsi, along with other health benefits is known to have anti-infective functions. Oscimun sanctum can be used as antiviral agent for effective control of viral infections of animal importance. Some of the phytochemical constituents of tulsi are oleanolic acid, ursolic acid, rosmarinic acid, eugenol, carvacrol, linalool, $\beta$-caryophyllene (about 8\%). Tulsi, along with other health benefits is known to have anti-infective functions. Hence, antiviral activity of aqueous, ethanol, methanol and chloroform extract of powdered drugs was evaluated against economically important viruses of veterinary importance, Orthmyxovirus and Paramyxovirus. The in vitro cytotoxicity confirmed the safety of the extracts and aqueous extract showed no inhibition on paramyxovirus while showing moderate inhibitory activity on orthomyxovirus while ethanol extract showed moderate inhibitory activity on paramyxovirus and no activity on orthomyxoviruses. Methanol extract showed no inhibition of paramyxovirus while showed significant inhibition of orthomyxovirus. Chloroform extract of the plant showed no inhibition paramyxovirus while significant inhibition was observed on orthomyxoviurs. Results of the study suggest that the $\mathrm{O}$. sanctum can be used as antiviral agent for effective control of viral infections of animal importance [26-28]. 


\section{Tulsi Medicinal Uses \& Benefits}

Promotes Healthy Heart. Holy basil contains vitamin $\mathrm{C}$ and antioxidants such as eugenol, which protects the heart from the harmful effects of free radicals. ...

Anti-aging. ..Treats Kidney Stones. Relieves Headaches. Fights Acne. ...

Relives Fever. Eye Health. Oral Health.
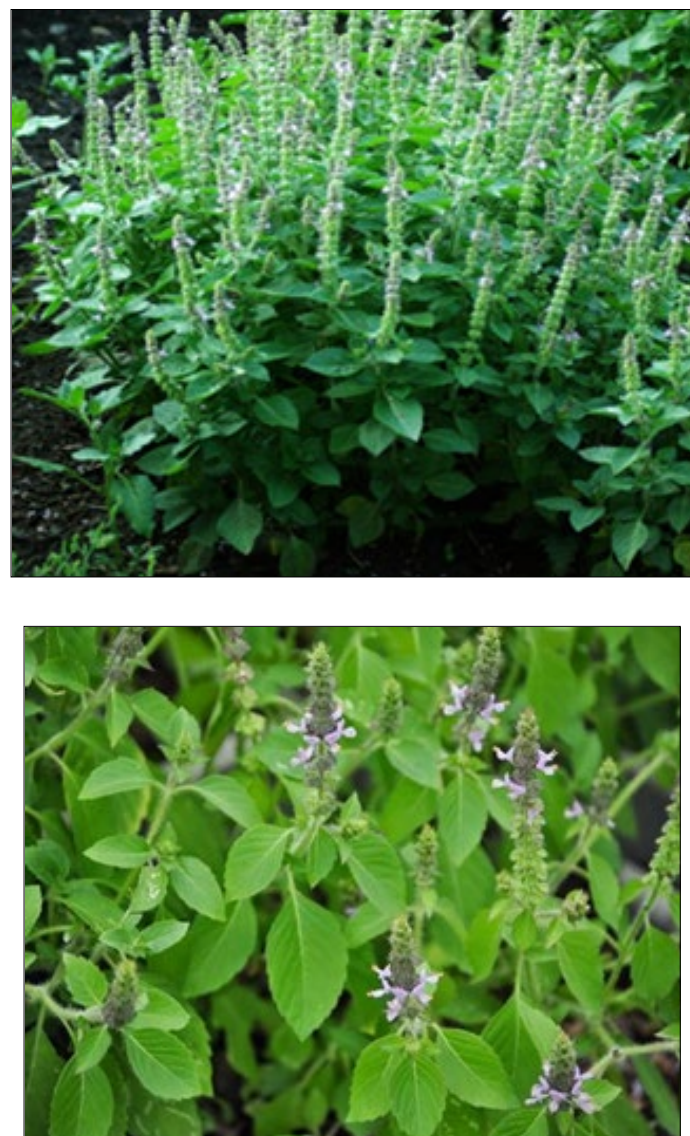

Images of Holy Basil Plant
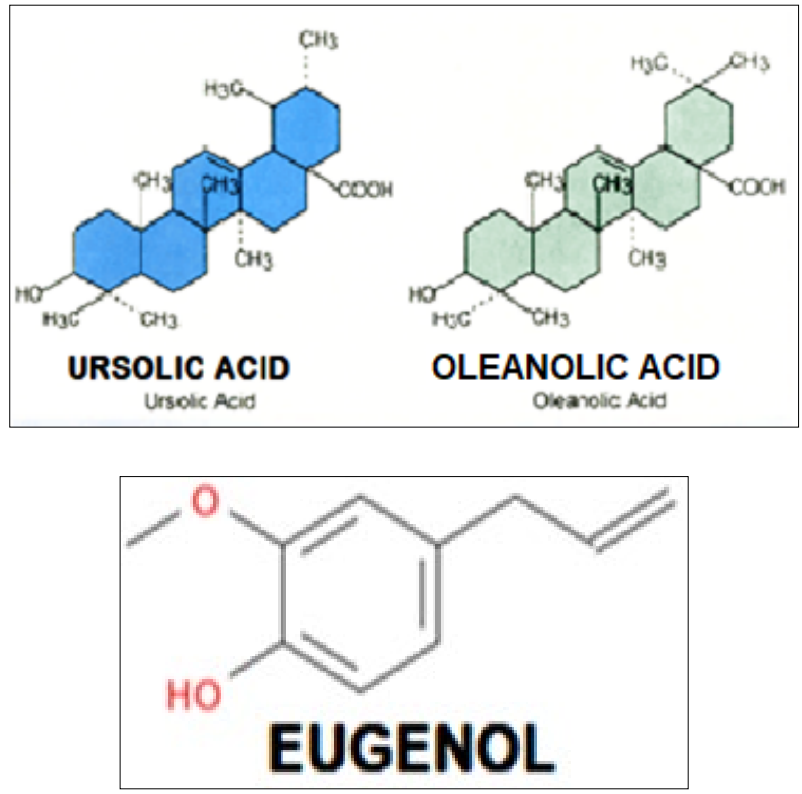
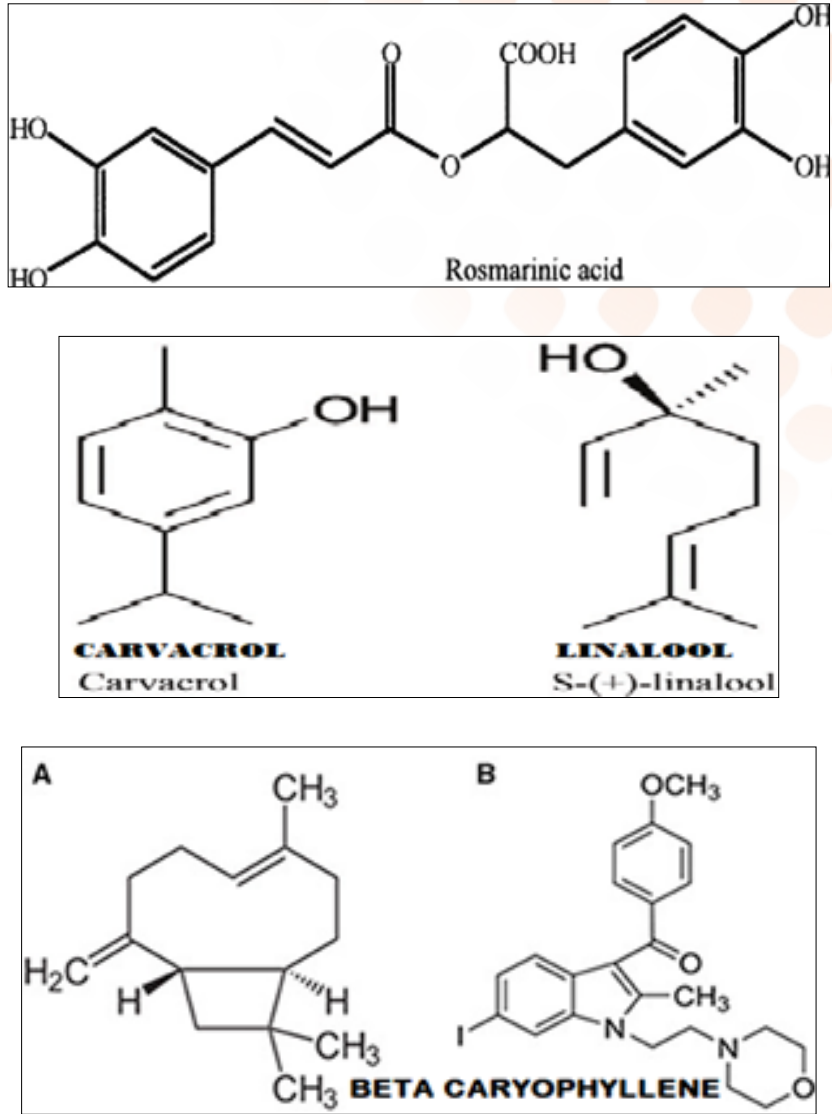

Chemical Structures of Ocimum Sanctum

\section{Menthe (Mint)}

Mint was originally used as a medicinal herb to treat stomachache and chest pains. There are several uses in traditional medicine and preliminary research for possible use in treating irritable bowel syndrome. Menthol from mint essential oil (40-90\%) is an ingredient of many cosmetics and some perfumes. The Mint: Mint aids digestion and settles the stomach. Mints (and lemon!) both contain potassium to help restore normal fluid balance and flush out bloat. Many overthe-counter cold and flu treatments contain menthol, a primary compound in peppermint oil.

Many people believe menthol is an effective nasal decongestant that can get rid of congestion and improve airflow and breathing. However, multiple studies show that menthol has no decongestant function. That being said, research also shows that menthol can subjectively improve nasal. This means that although menthol doesn't work as a decongestant, it can make people feel like they are breathing through their nose easier. This is likely to provide at least some relief to those affected by a cold or the flu.

\section{Chemical constituents of Mint}

Peppermint has high menthol content. The oil also contains menthone and carboxyl esters, particularly menthyl acetate. Dried peppermint typically has $0.3-0.4 \%$ of volatile oil containing menthol (7-48\%), menthone (20-46\%), menthyl acetate $(3-10 \%)$, menthofuran $(1-17 \%)$ and 1, 8-cineol (3$6 \%)$. 

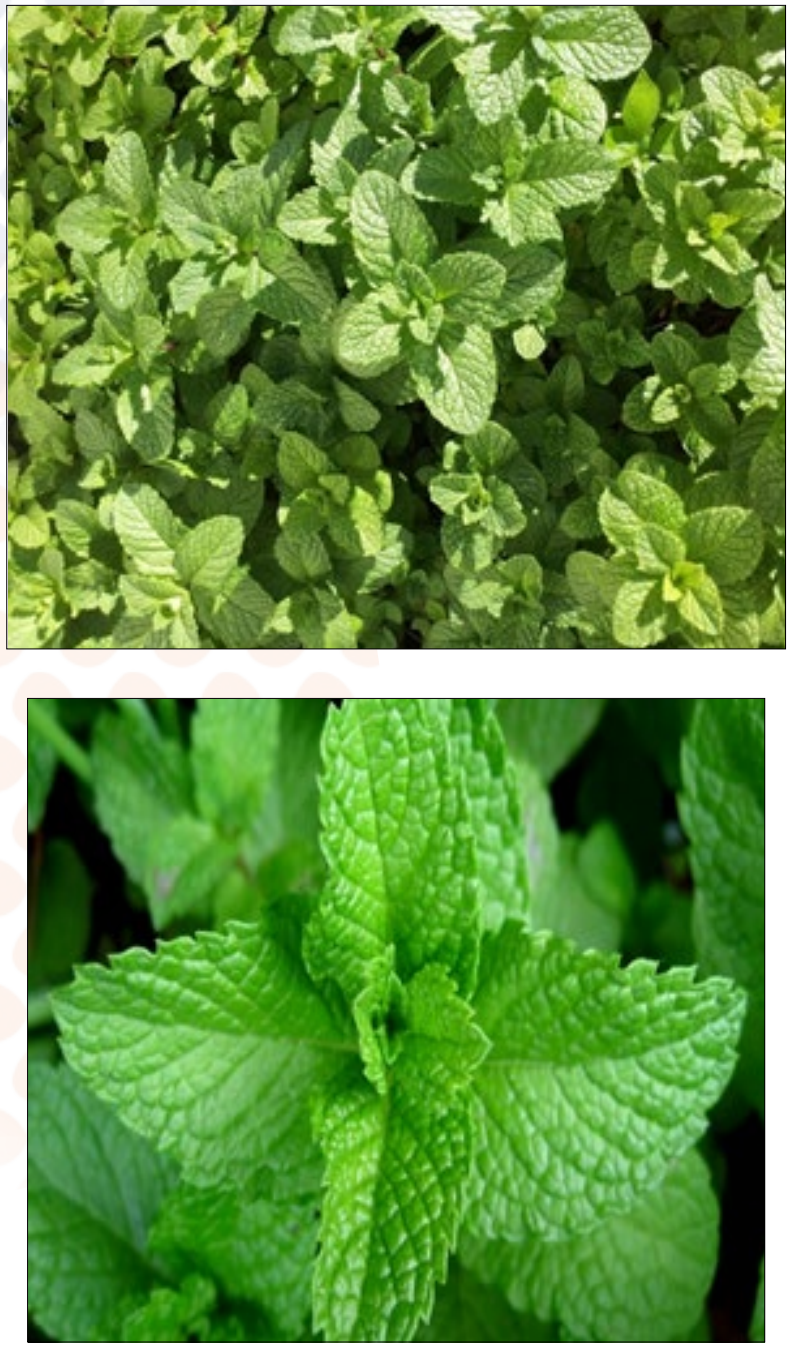

Images of Mentha (Mint) Plant

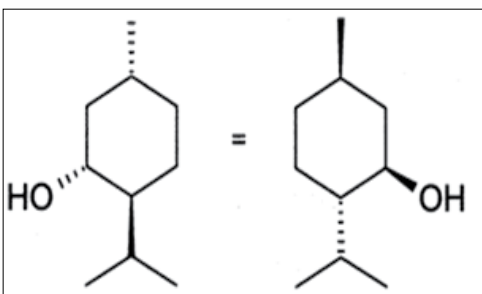

$(-)$-Menthol

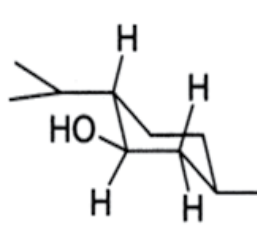

Chair form of $(-)-$ Menthol

\section{Chemical structure of Menthol}

The effect of immune system in SARS 2 (COVID-19) infection

Dendritic cells and macrophages are first line components of the innate immune network. DCs, which can be grouped into plasmacytoid (pDC) and myeloid types (mDC), play important roles in driving both innate and adaptive immune responses to viral pathogens. pDCs rapidly respond to viruses or their derivatives to produce large amounts of type I IFN, which can induce direct antiviral responses and also modulate other components of the innate and adaptive immune response, such as natural killer cells and CD8 T cells. Though less robust than pDCs, mDCs can also secrete large amounts of type I IFN.
However, mDCs also play a major role in stimulating acquired immune responses through their capacity as antigen presenting cells and producers of a wide array of immuno-modulatory cytokines. MPs are potent producers of type I IFNs and other pro-inflammatory cytokines that induce antiviral protection while also potentially contributing to immune pathology associated with viral infections. The acute phase of SARS in humans is associated with a severe reduction in the number of T cells in the blood. Surprisingly, only a limited number of studies have explored the role of the T cell-mediated adaptive immune response in respiratory coronavirus pathogenesis. The acute phase of SARS in human patients was associated with marked leukopenia with severe lymphopenia, involving a dramatic loss of CD4 T cells and CD8 T in comparison with healthy control individuals

The effects of very powerful immune booster juice recipe The alterations in the immune mechanism taken place in corona virus affected person can be revert back by the above mention medicinal plants and their chemical substances (alkaloids) with their highly potent antiviral activity which interacts and inactivate the pathogenesis and breaks further replication of corona viruses. The simple medicinal plants and their chemical substances enhance the immune system in the body by genesis of lymphocytes which develop in to CD4 T cells and CD8 T cells.

The alkaloids of the plants which are mentioned cannot directly be administered in the effected persons. It can be made into an immune booster juice recipe with the above mentioned plants in a specified pattern. Consuming this very powerful immune booster juice recipe will not cause of any neurological damage like loss of smell, loss of taste, neuromuscular disorders etc and at the same time it can protect the entire nervous system and rejuvenate the nerves where damage has taken place. It reduces the effect of virus and increases the immune power in the body and enhances the ability to fight diseases. It can induce bronchodilation and rapid relaxation by modulating intracellular calcium $\left[\mathrm{Ca}^{2+}\right]$ in airway smooth muscle (ASM). It can boosts and stimulates the immune system to kill viruses and has potential to reduce incidences of sore throat, provide quicker symptom relief, and improve recovery time. Immediately after drinking this juice recipe, the body's most powerful antibodies are produced and the virus injected into the body is inactivated. It can truly changes human lifestyle and strengthen body's natural defenses and help fight against harmful disease causing microorganisms. It really is the elixir of medicine that nature has given us. It will cure any ailments and keep everyone healthy. The importance of such generic herbs and its action potentiality is unknown to most in the world. Even if now, everyone knew the importance of it and everyone took it, be perfectly healthy and come out of this world.

The preparation methodology of the very powerful immune booster juice recipe

\section{Requirements}

1. Clean Copper Vessel/Bowl 
2. Grinder

3. Ten dried Black Pepper Seeds

4. Two dried Long Pepper Seeds

5. Thumb sized Ginger

6. Non adulterer Turmeric Powder about one tea spoonful

7. One fresh Fruitful Lemon

8. Fresh Crushed Garlic Cloves

9. Ten Fresh Holy Basil Leaves

10. Ten Fresh Menthe (Mint) Leaves

\section{Procedure}

Take a clean small copper metal bowl; add to it, ten dried seeds of black pepper, two dried seeds of long pepper, thumb size fresh ginger, one tea spoonful of pure turmeric powder, two to three crushed garlic cloves, one fresh fruitful lemon with rind, ten holy basil leaves and ten menthe leaves (Mint). Grind all the ingredients until converts in to liquid form and the fresh recipe is ready for the use.

\section{Treatment/management of viral infections}

Treatment in adults

1. A very powerful immune booster juice recipe $30 \mathrm{ml}$ swallowed twice daily morning and night before food for seven days ( It's a very powerful immune booster recipe, it can rapidly develop antibodies against foreign bodies and immediately after intake of this recipe can set on improving weakened and suppressed immune system. It hinders the viruses' replication; drastically reduce viral virulence and viral load.)

2. Tablet Vitamin D3 $60 \mathrm{~K}$ once in a week for two months and fifteen days (It can fight against any kind of infections include COVID 19)

3. Tablet Multivitamin with zinc one per day (Multivitamins can activate internal organic functions, improve normal metabolic rate, these are the antioxidants help in stimulation and activate immune system to fight against harmful pathogenic organisms and reduce radicals)

4. Tablet Paracetamol can be given when patient suffers from fever.

5. Hydration of the body with 3 to 4 liters of pure water (Hydration very important of overall health. It can eliminate toxic substances accumulated in the body through urination and sweat. It maintains body temperature and fluid balance. Hot climates and more workouts need adequate water intake to combat dehydration. Thirstiness and yellowish urination is an indication of dehydration. In case of diabetes mellitus excessive urination lead to dehydration, in such cases rehydration can carefully be maintained. Rehydration can be done in the form of tea, coffee, juice and water).

6. Daily moderate exercise for 15 to 30 minutes (Many research studies have reported with practical evidences that a single session of moderate exercise boost the effectiveness of immune systems where as intense exercise can suppress the immune system. Regular practice of moderate exercise can reduce inflammation and can also be regenerate immune cells. Moderate exercise in the sense - jogging, brisk walking, cycling, swimming and climbing stairs).

7. Limit in sugar intake (Regular intake of sugar may lead to obesity).

8. Balanced diet with plant origin - (Fruits, Vegetables, Green Vegetables, Nuts, Seeds, Legumes, Sprouted seeds etc. are rich in nutrition, reduce unwanted fats, cholesterol, triglyceride levels and develop high density lipids and antioxidants help against harmful functional disorders and pathogens. It can also develop gut flora which prevent chronic constipation and restore normal bowel movements. All the plant foods can lower susceptibility to illness).

9. Enough Sleep - Poor sleep is highly susceptible to sickness. Good sleep strengthens natural immune system to better fight the illness. Adults should get at least seven to eight hours of sleep per night. Adequate sleep gets rid of tiredness, fatigue, lassitude, extreme weakness and restores energy of the body.

10. Regular salt water gurgling thrice a day for one week

11. Strict maintenance of personal and environmental hygiene

\section{Treatment in Children}

Very Powerful immune booster juice recipe can be allowed to swallow $15 \mathrm{ml}$ twice daily morning and night before food intake. Multiple vitamins with zinc can be given in the form of syrup about 3 to $5 \mathrm{ml}$ once a day and at the same time Vitamin D3 sachets are suggestive in children weekly once. Rest of the management same as adult management.

\section{Conclusion}

People around the world commonly get infected with human corona viruses 229E, NL63, OC43, and HKU1. Sometimes corona viruses that infect animals can evolve and make people sick and become a new human corona virus. 3 recent examples of this are 2019-n CoV, SARS-CoV, and MERS-CoV. These viruses became as a storm on our world and wiped out so many people. The world is currently ravaged by this deadly virus. No country in the world has been able to find drugs for it except social distancing, self quarantine and country wide lockdown. But there are traditions and customs in India. Mostly in Hindu traditional dishes made of turmeric, black pepper, ginger, garlic, cumin seeds, lemon, citrus, cloves, coriander leaves, mint leaves and curry leaves all these have great immunity. The immunity of the Indian people is so high that the Corona Virus is unable to cope with the people of India. In view of all this, very powerful immune booster recipe was made. It has good properties and good results for all who used it in India. Therefore, I sincerely wish to use this powerful immune booster recipe all over the world to rid the world of Corona pandemic.

\section{Acknowledgement}

First and foremost, praises and thanks to the God, the Almighty and to my father Tadepalli Chandra Sekharam, Driver of Superfast Express Trains in Indian Railways and Former President of Loco Running Staff Association, South Eastern Railway, Visakhapatnam and my mother Tadepalli Nagamani, 
who gave birth to me for their showers of blessings throughout my research work to complete successfully. They have my lifelong salutations.

I would like to express my gratitude to my Guru (the teacher) Dr. M. S. Giri Varma MA(Lit), MBBS, FRSH (London), PGMVWO, B. Sc, PGIPM, (D.I.G: B.Ed; M.Sc, P.H, - U.K, M.P.H - U.W.I); Former District Medical Officer-2 (British West Indies). In fact, with his inspiration, I stand before you today as a doctor.

I would like express my gratitudes to my Professors Dr. B. Rama Rao, MD, Dr. Rajanarasimham, MD, Dr. K. Surya Kumar, MS, Dr. Jaya Sankar, MS, Dr. Pushpa Latha, MD, Dr. K. Ramanjaneyulu, MD, Dr. Chakravarthy, MD, and Dr. Dharma Lingam and Mrs. Dr. Dharma Lingam, Chairman's of Dharma Medical Colleges, Sriperumbudur, Chennai, Tamilnadu, they have also uncovered my hidden talents to teach me well.

I wish to acknowledge my wife Tadepalli Sunita Kumari, General Secretary of JSMKDO, my elder son Dr. Tadepalli Pradyumna (MD - General Medicine), Vice President of JSMKDO, and my younger son Mr. Tadepalli Jai Chandra Sai, Joint Secretary, JSMKDO, provided great support and consideration in every aspect to complete this research project.

\begin{tabular}{|c|c|c|c|c|c|c|}
\hline $\begin{array}{l}\text { Patient } \\
\text { Category }\end{array}$ & $\begin{array}{l}\text { No of Patients } \\
\text { Attended }\end{array}$ & Age Group & $\begin{array}{l}\text { Patient Complaints } \\
\text { Signs and } \\
\text { Symptoms }\end{array}$ & $\begin{array}{l}\text { Treatment Given } \\
\text { One Week }\end{array}$ & $\begin{array}{l}\text { Complete } \\
\text { Recovery } \\
\text { Obtained }\end{array}$ & $\begin{array}{l}\text { Complaints exist and } \\
\text { Recovered }\end{array}$ \\
\hline Adult Male & 24 & $60-85$ & $\begin{array}{l}\text { Fever, Headache, } \\
\text { Body Pains, LBA, } \\
\text { Productive Cough, } \\
\text { mild Cold and mild } \\
\text { running nose, mild } \\
\text { to moderate Throat } \\
\text { Pain, Hypertension } \\
\text { and Extreme } \\
\text { Weakness }\end{array}$ & $\begin{array}{l}\text { Adult Treatment } \\
\text { ( } 1 \text { to } 11) \text { is } \\
\text { strictly followed } \\
\text { for one week }\end{array}$ & $\begin{array}{l}24 \text { out of } 24 \\
\text { were completely } \\
\text { recovered and } \\
\text { feeling good } \\
\text { with normal } \\
\text { vitals }\end{array}$ & $\begin{array}{l}\text { No evidence of } \\
\text { further complaints } \\
\text { reported from the } \\
\text { patients }\end{array}$ \\
\hline Adult Women & 27 & $60-85$ & $\begin{array}{l}\text { Fever, Headache, } \\
\text { Body Pains, LBA, } \\
\text { Productive Cough, } \\
\text { mild Cold and mild } \\
\text { running nose, mild } \\
\text { to moderate Throat } \\
\text { Pain, Hypertension } \\
\text { and Extreme } \\
\text { Weakness }\end{array}$ & $\begin{array}{l}\text { Treatment (1 } \\
\text { to } 11) \text { is } \\
\text { strictly followed } \\
\text { for one week }\end{array}$ & $\begin{array}{l}23 \text { out of } 27 \\
\text { were completely } \\
\text { recovered and } \\
\text { feeling good } \\
\text { with normal } \\
\text { vitals }\end{array}$ & $\begin{array}{l}\text { The symptoms were } \\
\text { exist for three more } \\
\text { days due to irregular } \\
\text { consuming medicine }\end{array}$ \\
\hline $\begin{array}{l}\text { Middle age } \\
\text { Male }\end{array}$ & 54 & $35-60$ & $\begin{array}{l}\text { Fever, Body Pains, } \\
\text { Productive Cough, } \\
\text { mild Cold, running } \\
\text { nose, moderate } \\
\text { Throat Pain and } \\
\text { Extreme Weakness }\end{array}$ & $\begin{array}{l}\text { Treatment (1 } \\
\text { to } 11) \text { is } \\
\text { strictly followed } \\
\text { for one week }\end{array}$ & $\begin{array}{l}49 \text { out of } 54 \\
\text { were completely } \\
\text { recovered and } \\
\text { feeling good } \\
\text { with normal } \\
\text { vitals }\end{array}$ & $\begin{array}{l}\text { The symptoms } \\
\text { were exist still and } \\
\text { continued treatment } \\
\text { for } 3 \text { days more }\end{array}$ \\
\hline $\begin{array}{l}\text { Middle age } \\
\text { Women }\end{array}$ & 52 & $35-60$ & $\begin{array}{l}\text { Fever, Body Pains, } \\
\text { Productive Cough, } \\
\text { mild Cold, running } \\
\text { nose, moderate } \\
\text { Throat Pain and } \\
\text { Extreme Weakness }\end{array}$ & $\begin{array}{l}\text { Treatment (1 } \\
\text { to } 11) \text { is } \\
\text { strictly followed } \\
\text { for one week }\end{array}$ & $\begin{array}{l}45 \text { out of } 52 \\
\text { were completely } \\
\text { recovered and } \\
\text { feeling good } \\
\text { with normal } \\
\text { vitals }\end{array}$ & $\begin{array}{l}\text { The symptoms } \\
\text { were exist still and } \\
\text { continued treatment } \\
\text { for } 3 \text { days more }\end{array}$ \\
\hline Male children & 28 & $6-15$ & $\begin{array}{l}\text { Fever, Body Pains, } \\
\text { Productive Cough, } \\
\text { mild Cold, running } \\
\text { nose, moderate } \\
\text { Throat Pain and } \\
\text { Extreme Weakness }\end{array}$ & $\begin{array}{l}\text { Children } \\
\text { management } \\
\text { for one week is } \\
\text { strictly followed } \\
\text { as described }\end{array}$ & $\begin{array}{l}28 \text { out of } 28 \\
\text { were completely } \\
\text { recovered and } \\
\text { feeling good } \\
\text { with normal } \\
\text { vitals }\end{array}$ & $\begin{array}{l}\text { No evidence of } \\
\text { further complaints }\end{array}$ \\
\hline
\end{tabular}




\begin{tabular}{|l|l|l|l|l|l|l|}
\hline $\begin{array}{l}\text { Female } \\
\text { Children }\end{array}$ & $23-15$ & $\begin{array}{l}\text { Fever, Body Pains, } \\
\text { Productive Cough, } \\
\text { mild Cold, running } \\
\text { nose, moderate } \\
\text { Throat Pain and } \\
\text { Extreme Weakness }\end{array}$ & $\begin{array}{l}\text { Children } \\
\text { for one week is } \\
\text { strictly followed } \\
\text { as described }\end{array}$ & $\begin{array}{l}\text { leeling good } \\
\text { recovered and } \\
\text { with normal } \\
\text { vitals }\end{array}$ & $\begin{array}{l}\text { Treatment continued } \\
\text { obtained }\end{array}$ \\
\hline
\end{tabular}

\section{Data of One Month Patient's Clinical Report}

\section{References}

1. https://www.who.int/health-topics/coronavirus\#tab=tab_1

2. Kahn Jeffrey S, McIntosh Kenneth (2005) History and Recent Advances in Coronavirus Discovery. The Pediatric Infectious Disease Journal 24: S223-S227.

3. Kaja Zuwała, Anna Golda, Wojciech Kabala, Michał Burmistrz, Michal Zdzalik, et al. (2015) The Nucleocapsid Protein of Human Coronavirus NL63. PLoS ONE 10: e0117833.

4. Krzysztof Pyrc, Ben Berkhout, Lia van der Hoek (2007) The Novel Human Coronaviruses NL63 and HKU1. JOURNAL OF VIROLOGY 81: 3051-3057.

5. https://en.wikipedia.org/wiki/Coronavirus

6. https://www.sinobiological.com/research/virus/sarscoronavirus-overview

7. https://www.google.com/search?q=structure + of + co ronavirus + with + labelling \& tbm $=i s c h \& v e d=2 a h U K$ EwiZ2d-CxtHoAhVQBHIKHQNyAmMQ2-cCegQ IABAA\&oq=coronavirus + with+labelling\&gs_lcp $=\mathrm{CgNpbWcQARgAMgYIABAFEB} 46 \mathrm{BAgAEEM}$ 6AggAOgYIABAIEB5Qi4cIWIzACGCZ2QhoAH AAeACAAW-IAd4LkgEENS4xMJgBAKABAaoB $\mathrm{C} 2 \mathrm{~d} 3 \mathrm{cy} 13 \mathrm{aXotaW} 1 \mathrm{n} \&$ sclient $=\mathrm{img} \& \mathrm{ei}=9 \_\& \mathrm{bih}=69$ $5 \&$ biw $=1366 \&$ safe $=$ off $\#$ imgrc $=$ RxZ106cYFaKRfM

8. David AJ Tyrrell, Steven H Myint (1996) Chapter 60Coronaviruses. ncbi.nlm.nih.gov/books/NBK7782/

9. https://en.wikipedia.org/wiki/Coronavirus

10. https://www.sinobiological.com/research/virus/ coronavirus-replication

11. https://hot-topics.globaldata.com/immuno-oncologymarket/?utm_source $=\& u t m \_$medium

12. Coronavirus treatment: Vaccines/drugs in the pipeline for COVID-19. https://www.clinicaltrialsarena.com/analysis/ coronavirus-mers-cov-drugs/

13. Oriol Mitjà, Bonaventura Clotet (2020) Use of antiviral drugs to reduce COVID-19 transmission. Lancet Glob Health S2214-109X: 30114-30115.

14. https://www.eurekalert.org/pub_releases/2020-04/uoncana040320.php

15. http://theconversation.com/in-the-fight-againstcoronavirus-antivirals-are-as-important-as-a-vaccineheres-where-the-science-is-up-to-133926

16. Coronavirus: what happens to people's lungs when they get Covid-19? (2020) https://www.msn.com/en-in/health/ familyhealth/coronavirus-what-happens-to-peopleslungs-when-they-get-covid-19/ar-BB11snd8

17. https://www.sciencedirect.com/topics/agricultural-andbiological-sciences/piperine
18. Peyman Mikaili, Surush Maadirad, Milad Moloudizargari, Shahin Aghajanshakeri, Shadi Sarahroodi (2013) Therapeutic Uses and Pharmacological Properties of Garlic, Shallot, and Their Biologically Active Compounds. Iran J Basic Med Sci 16: 1031-1048.

19. https://www.sciencedirect.com/topics/pharmacologytoxicology-and-pharmaceutical-science/piper-longum

20. 20. Çifci A, Tayman C, Yakut Hİ, Halil H, Çakır E, et al. (2018) Ginger ( Zingiber officinale ) prevents severe damage to the lungs due to hyperoxia and inflammation. Turk J Med Sci 48: 892-900.

21. https://visihow.com/Use_Ginger to Improve_Your Respiratory_System

22. h t t p s : / / w w w . g o o g 1 e . c o m / search? safe $=$ off\&sxsrf $=$ ALeKk01t_GVlsNZdqjw RoJpchWEpxvJhTw\%3A1586258633523\&lei=y WKMXoK 8 H 5 iM4-EPscGt8 AE\&q=ginger $\% 20$ b r o n c hodilat or \& v ed $=2$ a h UKEwiv OfzmdboAhXqxTgGHTcXA4MQsKwBKAF6BAgHEAI\&biw $=1366 \&$ bih $=695$

23. Elizabeth A Townsend, Matthew E Siviski, Yi Zhang, Carrie Xu, Bhupinder Hoonjan, et al. (2013) Effects of Ginger and Its Constituents on Airway Smooth Muscle Relaxation and Calcium Regulation. Am J Respir Cell Mol Biol 48: 157-163.

24. https://www.sciencedirect.com/topics/agricultural-andbiological-sciences/curcuma-longa

25. Usha Patil (2018) Studies on Antiviral Activity of Tulsi (Ocimum Sanctum) Crude Extracts on Selected Viruses of Veterinary Importance. International Journal of Ayurveda and Pharma Research 6: 17-21.

26. https://www.healthline.com/nutrition/mintbenefits\#section6

27. Rudragouda Channappanavar, Jincun Zhao, Stanley Perlman (2014) T cell-mediated immune response to respiratory coronaviruses. Immunol Res 59: 118-128.

Copyright: (C2020 Surya Prakash Tadepalli.This is an open-access article distributed under the terms of the Creative Commons Attribution License, which permits unrestricted use, distribution, and reproduction in any medium, provided the original author and source are credited. 